\title{
Investigating the causality between financial inclusion, financial development and sustainable development in Sub-Saharan Africa economies: The mediating role of foreign direct investment
}

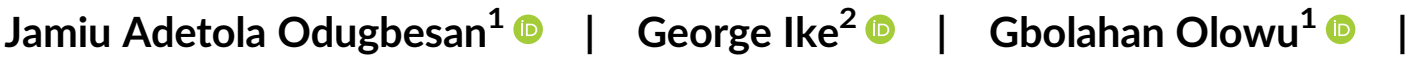 \\ Bosede Ngozi Adeleye ${ }^{3}$ (1)
}

${ }^{1}$ Department of Business Administration, Faculty of Economics and Administrative Sciences, institute of graduate studies, Cyprus International University, Nicosia, Turkey

${ }^{2}$ Department of Economics, Institute of Graduate Studies and Research, Faculty of Business and Economics, Eastern

Mediterranean University, Famagusta, Turkey

${ }^{3}$ Department of Economics and Development Studies, Covenant University, Ota, Nigeria

\section{Correspondence}

Odugbesan Jamiu Adetola, Department of Business Administration, Faculty of Economics and Administrative Sciences, Institute of Graduate Studies, Cyprus International University, via Mersin 10, North Cyprus, Turkey.

Email: odugbesanadetola@gmail.com
In developing economies, the role of the financial sector and foreign capital in the stimulation of sustainable production practices has not been very clear cut. In a bid to obtain a much clearer empirical perspective, the present study investigates the causal relationship between financial development, financial inclusion, foreign direct investment (FDI) and sustainable development in a panel of 33 Sub-Saharan African (SSA) economies within the 2004-2018 study periods. Panel cointegration tests uncover the presence of a long-run relationship among the variables in the model. Prior to determining the direction of causality, panel estimation procedures show the magnitude and signs of the long run coefficients. Panel Granger causality tests uncover bidirectional causality between financial inclusion and FDI as well as between financial development and FDI. Also uncovered is unidirectional causality from FDI towards sustainable development and resource rents. This study suggests that the policymakers in SSA should optimize the level of financial development which requires a vigorous improvement so as to ensure higher potential benefits for the sustainability of SSA region through financial sector.

\section{1 | INTRODUCTION}

The attention of scholars and policymakers on the issue of sustainability has been on the increase in recent times, owing to the economic and social progress, global financial crises, and accelerating environmental degradation which is inflicting costs on societies (DESA, 2013). Meanwhile, a mere continuation of current development strategies will not suffice to achieve sustainable development. The concept is being perceived as a complex one that covers cross-cutting issues (Odugbesan \& Rjoub, 2019). Even though the definition on the concept abounds in the literature, the definition by the World Bank that describes sustainable development as a "development path or structured principles that could be maintained to ensure the total welfare of the people does not decline along the path" (Odugbesan \& Rjoub, 2019: 2) has been the most acceptable one. In this definition, two notable points of reference are the significance of the people's welfare and the ability of the environment to meet the needs of the present without compromising the future.

Meanwhile, in the debates on the definitions of sustainable development over the past two decades, there are some common principles that have been emphasized, among which are: equity and fairness which implies that the vulnerable populations should be given priority to improve their conditions (Adegbite \& Machethe, 2020); the longterm perspective that forms the basis for precautionary principles; and, lastly the interconnection between the notable three dimensions of sustainable development (economic, environmental and social) (Yin, $\mathrm{Xu}$, Chen, \& Peng, 2019), and recently; governance, which was argued by Odugbesan and Rjoub (2019) as the fourth dimension, and that the four dimensions should be wholly integrated for the achievement of sustainable development. 
Moreover, despite the general acceptability that sustainable development appeals to the convergence of the three recognized dimensions (economic, environmental and social), the achievement of the concept remains elusive. Though, Matthews and Anne (2010) observed that the challenge is as a result of difficulties in the movement from theory to practice. Also, the study identified an impediment posed by development which was in reference to economic growth as a challenge. It was then concluded in the study that addressing these challenges calls for a profound structural change, most especially in developing countries, in respect to the manner in which the societies operate their social, environmental and economic affairs.

Sub-Saharan Africa (SSA) being a region that accommodates mostly developing countries presents a scenario that attracts the attention of these researchers. In reference to IMF (2019), the development in the SSA region presents a disturbing scenario that is of great concern, as the growth is projected to remain at $3.2 \%$ in 2019 and expected to rise to $3.6 \%$ in 2020 , which could not happen owing to the outbreak of the COVID-19 pandemic which has caused the projection to contract by -1.6 (IMF, 2020). Moreover, the growth in the region is observed to vary considerably across countries, and it is projected to continue (IMF, 2019). Other challenges bedeviling the region are the increase in inflation, public debt vulnerabilities and low external buffers, threat of increasing protectionism, reversal in capital inflows, climate shocks, security challenges, fiscal slippages and absence of reforms in key countries which could add to deficit and debt pressure. In addition, the spread of the COVID-19 pandemic that is already taking its toll on the region, and if not checked could reverse the gains of development in the region (IMF, 2020). All these challenges pose serious threats to the sustainable development of the region, and as such it is imperative to investigate the impact of some macroeconomic variables on the achievement of sustainable development in SSA.

Meanwhile, in recent times, the debates on financial development and financial inclusion have been ongoing around the world. It is no doubt that the issue of sustainable development with respect to the economy, environment and society develops a significant and quick growing demand for adequate financing and functional financial instruments and markets, which is also an important area that requires the application of sustainable finance and financial market policy (Asif et al., 2020; Ibrahim \& Alagidede, 2018). According to Yin et al. (2019), financial inclusion is described as the accessibility of "individuals and businesses to useful and affordable financial products and services that meets their transaction needs, payments, savings, credit and insurance-delivered in a responsible and sustainable way" (Yin et al., 2019: 1). Also, several studies have given credence to the significance of financial development to economic growth through the provision of efficient financial services (Ibrahim \& Alagidede, 2018). However, it was noted by Ibrahim and Alagidede (2016) that "while finance potentially spurs economic growth, the overall effects of finance crucially depends on the relative speed of economic growth".

A disturbing scenario is the report by World Bank that about 1.7 billion adults around the world are still unbanked, and these population groups are mostly composed of women and vulnerable households (Yin et al., 2019). This is an indication that it becomes imperative to investigate the influence of financial inclusion on the achievement of sustainable development in developing countries, most especially Sub-Saharan African (SSA) countries which is noted for having a large share of the world's vulnerable population. In reference to "sustainable development goals" (SDG), provision of financial inclusion will give support to vulnerable populations to have equal opportunities, assist them in reducing poverty which will bring about reduction in social inequality and eventual achievement of sustainable development (Yin et al., 2019).

In the report of Ernst and Young Global Limited (2015), it was argued that the financial service industry would play a prominent role in the achievement of sustainable development. It was in view of this report that Ceres (2016) suggested that the influence of financial markets in the achievement of sustainable development will be through its influence on capital across the world markets. Meanwhile, the study of Weber, Diaz, and Schwegler (2014) shows a low performance of the financial sector in terms of financial development, also, the inclusion of different stakeholders is still not clear.

Even though financial inclusion and financial development have been identified in the literature to contribute to the economic growth of a nation (Adegbite \& Machethe, 2020; Ibrahim \& Alagidede, 2018; Kim, Yu, \& Hassan, 2018), of which some countries, most especially developing countries have presented it in their policy documents as a tool for eradicating poverty, most of these countries have also been found not willing to serve the vulnerable segments of their populations (Anarfo \& Abor, 2020). This implies that accessibility to financial markets and the development of financial markets of developing countries in order to accommodate the vulnerable population remain a challenge, with a possible attendant influence on the achievement of sustainable development in those countries. Furthermore, according to Adegbite and Machethe (2020), financial inclusion for instance has the potential of enhancing the families of vulnerable population's ability to withstand financial shocks, enhancing human capital investments or undertaking a moderate accumulation of assets, so as to have an advantage of promising investment. However, there has been a paucity of studies that empirically investigates the causality of both financial inclusion and financial development in the achievement of sustainable development in SSA.

Of particular note is the role of foreign capital in sustainable development practices. Zarsky and Gallagher (2012) in their study allude to an inconsistent role of FDI in developing countries. These inconsistencies may arise due to the multiple and sometimes contrasting effects of FDI. Park (2018) uncovers a unidirectional causal flow from FDI to research and development (R\&D) and a bidirectional causal flow between GDP and the interaction of FDI and R\&D. This goes to show that FDI can affect development through multiple and sometimes disconnected transmission mechanisms. However, previous studies are more focused on the relationship of financial development, financial inclusion, natural rent and foreign direct investment (FDI) with economic growth, while studies on the effect of these 
macroeconomic variables on sustainable development have been scant in the literature.

In view of the above, it becomes imperative to empirically investigate the influence of financial inclusion and financial development on the achievement of sustainable development in SSA while paying particular attention to the mediating role of FDI. This study will contribute to the literature by investigating the causality between financial inclusion, financial development, natural resource rent, FDI and sustainable development in 33 SSA economies. Moreover, another contribution of this study will be in its determination of the signs and magnitude of the impacts, as well as investigating which of either financial inclusion or financial development has the stronger influence on the achievement of sustainable development in SSA and developing countries by extension. Therefore, the present study contributes to the extant literature in three folds. Firstly, by controlling for the triple effects of financial inclusion, financial development and FDI we are able to ascertain the nature of the relationship between all three variables and sustainable development and which of the two financial variables has a stronger relationship with sustainable development. Second, employing Panel Granger causality techniques, it can be inferred whether or not financial development, financial inclusion and FDI has any type of causal relationship with sustainable development. Third, we employ the Emirmahmutoglu and Kose (2011) (EK) panel Granger causality technique which allows for Granger causality testing in heterogeneous mixed panels regardless of whether the underlying variables are I(1) or I(0). It also controls for cross-sectional dependence through a bootstrap procedure. These qualities aid us to more effectively ascertain the true causal relationship between the variables under investigation

The remainder of the paper will consist of a review of relevant studies that will relate each of the variables in this study leading to the suggestion of a model that will illustrate the interactions between sustainable development, FDI, financial inclusion and financial development. Subsequent sections will describe the data and its sources, as well as the econometric estimators for the analysis, while variables operationalization and definitions will also be presented in this section. The paper will be rounded-up with the results, discussion and conclusions.

\section{2 | LITERATURE REVIEW}

Sustainable development as a concept captures both short- and longterm dimensions, being viable today and mindful of the future. However, financial development activities and goals are targeted toward immediate needs, which are not always of optimum benefit to the society (Acemoglu \& Wolitzky, 2015; Anwar, Shabir \& Hussain, 2011). Sustainable development is a focus of activities and deliberate actions to development today, bearing the future in mind. It is the aggregation and transformation of various capitals, from human, natural, and produced into means that support and improve economic, social and environmental development (Olowu, Bein, \& OlasehindeWilliams, 2018). Solving this dilemma often needs careful examination and orientation in most developing economies which Sub-Saharan
Africa has a large fair share of; by asking questions either to pursue immediate needs with its financial development endeavors; in the face of shared poverty and or seek sustainable development (Hatemi-J \& Shamsuddin, 2016; Jeanneney \& Kpodar, 2011; Uddin, Shahbaz, Arouri, \& Teulon, 2014).

Empirical findings on the relationship between financial development and sustainable development give mixed results. Several authors like Li, Zhang, and Ma (2015), Adeola and Evans (2017), Weber and Finance (2018) and Olowu, Olaseinde-Williams, and Bein (2019) have all reiterated in their various studies how financial development aids various indices of sustainable development, but of note is Weber and Finance (2018) which argues that although most governmental objectives and business goals on financial development are strongly inclined toward efficiency and cost savings rather than any social and environmental concern, financial development geared toward sustainable development is of utmost benefit to the society. Le, Chuc, and Taghizadeh-Hesary (2019), using a kernel density estimation method to analyze the relationship between financial development and the entrepreneurial endeavors of farmers in Chinese provinces, revealed that an increase in financial development aids sustainable development. Pradhan, Arvin, and Bahmani (2018) while investigating if innovation and financial development are causative agents to sustainable development using panel granger causality argue that there is a longrun relationship between financial development and sustainable development. Madsen et al. (2018:2) using panel data study to understand the relationship and effects of inequality, and financial development on the economic growth of $21 \mathrm{OECD}$ countries over a period of 142 years reveals that financial development has a positive trickling effect on bridging inequality gaps thereby bringing about sustainable development. Studies by Park and Shin (2017) advocate that financial development is a good ingredient for reducing income inequality up to a certain threshold and gives opportunity for a more sustainable society.

Koirala and Pradhan (2020) examine the factors that determine sustainable development, measured by adjusted net saving, using panel data for 12 Asian countries over a 25 year period, they argue that financial development is a major tool for sustainable development and that it also has a negative effect on inflation and natural resource rent thereby aiding a balance in natural resource exploitation.

Pardi, Salleh and Nawi (2017) while examining the determining factors that increase adjusted net savings (ANS) as a measure of sustainable development in Malaysia revealed that inflation rate, financial development, per capita income and natural resource rent have a strong impact on sustainable development both in the short and long term. Hess (2010) in a panel study to estimate the determinants of sustainable development. The research stated that the adjusted net saving rate is positively influenced by the initial level of human development, fraction of working-age population in the labor force, share of natural resources in exports and the level of financial development.

Gharleghi and Jahanshahi (2020) examine the impact of financial development and trade liberalization on income inequality as a measure of sustainable development in a sample of developed and developing countries. Using panel threshold analysis gives insight with empirical results that financial development is of great importance in 
decreasing income inequality only in countries with GDP per capita over $\$ 11,000$, but has no contributory effects or major impact in reducing inequality in developing countries. This implies that developing economies may have an altogether different story to tell as regards to the financial development-income nexus.

On the other note, Adeniyi, Oyinlola, Omisakin, and Egwaikhide (2015) using threshold modeling disagrees. Their findings about financial development and sustainable development differ from the aforementioned authors. Their study on Nigerian development while trying to analyze the financial development-growth nexus reveals that financial development actually mitigates economic growth in Nigeria over a 40-year period. They suggest that the sustainable development of a nation goes beyond just widening and improving the financial spectrum and engaging in financial reforms but wide and encompassing reforms and restructuring will be of greater benefit to development.

Studies also show that countries with natural resources do often suffer environmental degradation, inequality and political instability which hinder sustainable development and further corroborate the "financial resource curse" hypothesis. Moreover, financial development is a major aid for industrialization and a precursor for carbon emissions which thereby serves as a medium for endangering sustainable development (Acheampong, 2019; Asif et al., 2020: 2).

While analyzing the relationship between financial inclusion and sustainable development in China, findings reveal that sustainable development and financial inclusion require an enabling and conducive environment to have positive effects on each other. Also, the right coordination is needed to bring financial inclusion to aid sustainable development (Yin et al., 2019: 2).

In furtherance to the discussion on the relationship between financial inclusion and sustainable development, Sarma and Pais (2011) found that the level of human development and financial inclusion in a country tend to move closely with each other. Lenka and Bairwa (2016) conducted a study of SAARC countries and stated that if there is a sizeable improvement in financial inclusion, it might be of great help to decrease the inflation rate in an economy, which presents a positive relationship between financial inclusion and sustainable development. Financial inclusion has been proposed as an aid to sustainable development because it serves as a vehicle that aids poverty reduction, economic growth, thereby creating a society that is all inclusive (Demirguc-Kunt , Klapper, \& Singer, 2017).

Evans (2016) argues that improved financial inclusion in African countries does not facilitate or serve as a significant motivation of financial development effectiveness but financial development effectiveness aids financial inclusion. Čihák, Mare, and Melecky (2016) give an intertwined relationship between financial inclusion and financial development, which could be negative or positive based on policy settings, designs and how these policies are finally implemented.

Le et al. (2019), examining the trend in financial inclusion and its effect on sustainability in 31 Asian countries, revealed that availability of policy synergy exists between financial inclusion and financial development in those countries but an opaque side to their argument is that financial inclusion often aids the growth of financial inefficiency thereby bringing about a deteriorating effect on financial development. Increasing financial inclusion does not result in economic growth and development itself is a major driver for sustainable development which therefore affects the economic indicators positively (Babajide, Adegboye, \& Omankhanlen, 2015).

Moving on to the FDI-development nexus, Soumaré (2015) finds a positive, robust and significant welfare inducing effect for FDI in North African countries. His findings also show that FDI inflow to these countries is concentrated in very few industries notably the extractive petroleum and services industries with relatively lesser inflows channeled toward the labor intensive nonextractive primary industries. This goes to show that the effect of FDI in sustainable development greatly depends on the nature of the industries which attract FDI.

Azman-Saini, Law, and Ahmad (2010) suggest that the effect of FDI on economic growth is contingent on other factors. Employing a threshold model and utilizing data for 91 countries, their findings show that the positive effect of FDI on economic growth is only valid after financial market development exceeds a certain threshold. Their findings imply that FDI inflows need strong financial markets in order to generate positive spillover effects on other sectors of the economy and are consistent with the study by Choong (2012) where it is found that sound domestic financial markets are required in order for an economy to benefit from the positive effect of FDI.

The various literature discussed above have brought these conclusions. First, studies have revealed that there is a relationship between financial development, financial inclusion and sustainable development in various countries with mixed results. Second, most studies in the literature have examined these variables' effect on nations in the context of economic growth and not sustainable development. Third, even though several researchers have investigated the associations between financial development and financial inclusion, empirical contributions addressing the relationship of financial development, financial inclusion, FDI, and sustainable development in Sub-Saharan African countries as of the time of writing is nonexistent in the literature. The objective of this article is thus intended to fill these gaps.

\section{I DATA AND METHODOLOGY}

We employ annual data that cover the period from 2004 to 2018 , which include 33 SSA countries. The choice of countries and period in the panel were based on the data availability of the variables included in the study and were sourced from the World Bank's World Development Indicators (WDI) database and the International Monetary Fund's (IMF) International Financial Statistics (IFS). The ANS (measured as the gross national savings, less the value of consumption of fixed capital) was employed as a proxy for sustainable development. ANS has been argued for and used in the literature to be a good indicator for measuring sustainable development from an economic perspective (Gnègnè, 2009; Lange, Wodon, \& Carey, 2018; Nourry, 2008; Odugbesan \& Rjoub, 2019; Thiry \& Cassiers, 2010). FDI (inflow) and natural resource rents are obtained from the World Development Indicators. As for financial development, the newly computed index that summarized the development of financial 
institutions and financial markets in terms of their depth, access and efficiency was employed to measure financial development (Svirydzenka, 2016). The index was obtained from IFS. While data for financial inclusion use the following indices: number of ATMs per 100,000 adults, number of commercial bank branches per 100,000 adults, number of borrowers from commercial banks per 1,000 adults, number of deposit accounts with commercial banks per 1,000 adults, number of depositors with commercial banks per 1,000 adults and number of life insurance policies per 1,000 adults are obtained from IFS, these indices are used to develop the financial inclusion index through principal components analysis.

\section{1 | Developing a composite financial inclusion index}

Financial inclusion entails the degree of accessibility of financial services to all the citizens of a particular economy. There are quite a number of indicators that can be used to capture this variable which includes number of ATMs per 100,000 adults, number of commercial bank branches per 100,000 adults, number of borrowers from commercial banks per 1,000 adults, number of borrowers from commercial banks per 1,000 adults, number of deposit accounts with commercial banks per 1,000 adults, number of depositors with commercial banks per 1,000 adults and number of life insurance policies per 1,000 adults. These variables cannot all be included in the same model because of the high potential of multicollinearity and the loss of degrees of freedom. Constructing a composite financial inclusion index enables the capturing of the direction of maximum variation between all the aforementioned variables in order to more holistically analyze the Sustainable development effects of financial inclusion in SSA economies. Developing a financial inclusion index follows several studies in the literature (Babajide et al., 2015; Kim et al., 2018; Le, Le, \& Taghizadeh-Hesary, 2020; Anarfo \& Abor, 2020). In the following analysis, the $\imath$ th component would be employed in the analysis if:

$$
\lambda_{l}=\frac{1}{L} \sum_{l}^{L} \lambda_{l}=\frac{1}{L} I
$$

From Equation (1), $L$ is indicative of the rank of the matrix $\mathbf{X}$ which denotes the set of data to be analyzed. The data set is composed of $I$ observations and described by $J$ variables. For correlation-type PCAs, this would imply that an eigenvalue greater than 1 entails that the indicator is significant enough to be employed in the empirical analysis (Abdi \& Williams, 2010; Kaiser, 1961). Results from Table 1 shows that, of the six components extracted from the dataset, only one component is suitable enough to be employed in the empirical analysis as the proportion of variance explained by it is about $61.8 \%$ with an eigenvalue of 3.7 .

\section{2 | The model}

Within a panel framework, the long-run relationship between sustainable development, financial inclusion, financial development and FDI was modeled explicitly in Figure 1 and as follows:

$$
S D_{i t}=\beta_{0}+\beta_{1} F D I_{i t}+\beta_{2} F I_{i t}+\beta_{3} F D_{i t}+\beta_{4} R R E N T_{i t}+u_{i t}
$$

From Equation (2), SD, FDI, FII, FD and RRENT denotes, respectively, sustainable development (ANS as a proxy), FDI, financial

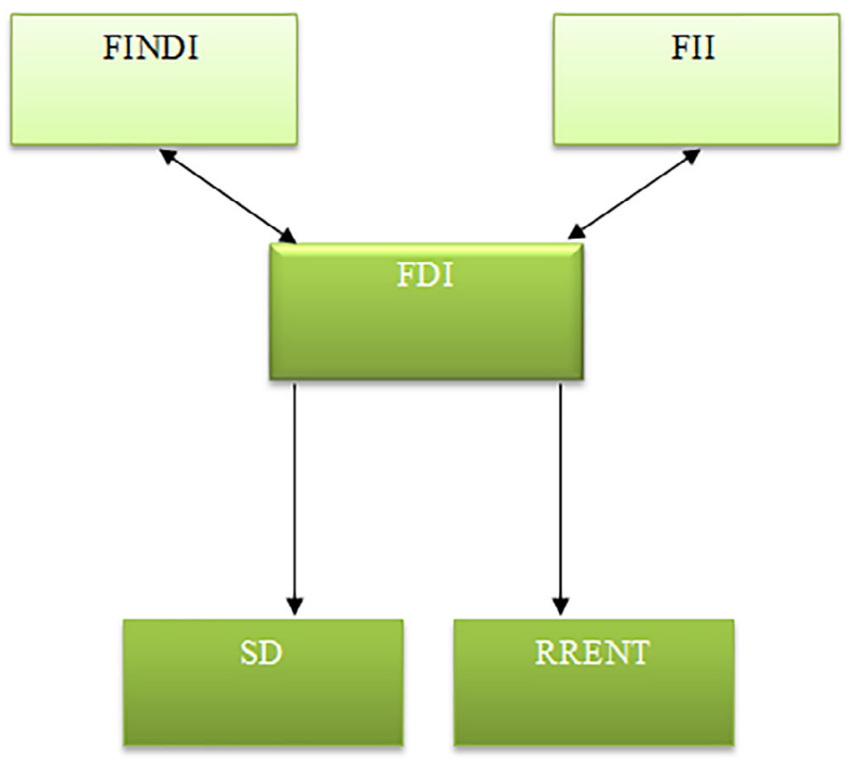

FIGURE 1 The mediating effect of FDI on sustainable development

TAB LE 1 Principal component analysis of financial inclusion

\begin{tabular}{lllll}
$\begin{array}{l}\text { Principal } \\
\text { component }\end{array}$ & Eigenvalues & $\begin{array}{l}\text { Cumulative } \\
\text { eigenvalues }\end{array}$ & $\begin{array}{l}\text { Percentage of } \\
\text { variance } \\
\text { extracted }\end{array}$ & $\begin{array}{l}\text { Cumulative } \\
\text { percentage } \\
\text { of variance extracted }\end{array}$ \\
\hline 1 & 4.974500 & 4.974500 & 0.8291 & 0.8291 \\
\hline 2 & 0.812751 & 5.787251 & 0.1355 & 0.9645 \\
\hline 3 & 0.178866 & 5.966116 & 0.0298 & 0.9944 \\
\hline 4 & 0.021913 & 5.988029 & 0.0037 & 0.9980 \\
\hline 6 & 0.010913 & 5.998943 & 0.0018 & 0.9998 \\
\hline
\end{tabular}


inclusion index, financial development and resource rent as a percentage of GDP. $\beta_{0}, \beta_{1}, \beta_{2}, \beta_{3}$ and $\beta_{4}$ are parameters to be estimated, while $u_{i t}$ is the composite error term which is assumed to follow a stochastic Gaussian process. The selection of the control variables is motivated by various factors. FDI represents capital inflows from external economies and so an increase in its level would entail the presence of a favorable investment climate. This would have a resultant influence on sustainable development. The direction and magnitude of this effect would depend on the intensity of FDI and the particular sector(s) of the economy where FDI may be attracted to. If FDI flows into the dirty industrial sectors, then sustainable development may be compromised if cleaner production practices are not encouraged. We also control for natural resource rents which is expected to have a negative relationship with sustainable development as natural resource depletion is deemed to be unsustainable in the long-run (Figure 1). It is necessary to control for natural resource rents because of its potential confounding effects on financial inclusion and financial development and FDI inflows. This is because of the potential role of the financial sector in intermediating resource booms (Beck \& Poelhekke, 2017) and its role in attracting FDI inflows. Financial development and financial inclusion are both indicators of the overall health of the financial sector. However, while financial sector development is oriented toward financial depth, efficiency and stability, financial inclusion is more oriented toward more inclusive access to financial services with the sole aim of improving information dissemination, reducing transaction costs and increasing investment and productivity by optimizing capital flows (see Beck, Demirgüç-Kunt, \& Levine, 2000, 2010).

\section{3 | Cross-sectional dependence and unit root test}

Before undertaking the empirical analysis, some preliminary tests need to be undertaken to understand the nature of the data and also what estimation methods would best suit the empirical analysis. To this end, we employ the Pesaran (2004) cross-sectional dependence test to establish if cross-sectional dependence exists within the data. This is because cross-sectional dependence can potentially distort the true parameter values of estimated models. Cross-sectional dependence can arise due to unobserved common factors such as global and regional shocks and thus can significantly diminish panel data efficiency gains if overlooked (Pesaran, 2004; Phillips \& Sul, 2003). In order to produce robust coefficient estimates, this issue needs to be put into consideration.

In order to empirically determine the integrating properties of the variables under investigation, we employ the Pesaran (2007) panel unit root test which allows for heterogeneity in the auto-regressive coefficient of the Dickey Fuller regression. The test controls for crosssectional dependence by controlling for the presence of a single common factor which is unobserved with factor loadings that are heterogeneous in the data. We employ this unit root testing procedure in order to mitigate the potential distorting effects of cross-sectional dependence in the unit root test results.

\subsection{Panel cointegration test}

If all the variables follow I(1) processes, then they would have to be cointegrated in order for a stable long-run relationship to exist. In order to establish the existence of a stable long-run relationship amongst the variables, we employ both the Pedroni $(1999,2004)$ and the Kao (1999) panel cointegration test procedures. Within the framework of Pedroni (1999, 2004), short-run parameters and individualspecific deterministic trends are filtered out in the first step of the procedure. This is an effective way of controlling for heterogeneity. Drawing from estimated residuals, Pedroni (2004) introduces five different test statistics, three of which follow a common process, generally denoted as "pooled" or "within-dimension" tests, and two assume individual processes denoted as "grouped" or "between-dimension" tests. Because of the relatively short individual time series, the present study will adopt only the three "within dimension" test statistics. The Kao (1999) cointegration test unlike Pedroni (1999) does not assume strict exogeneity of the regressors and also controls for fixed effects in the cointegrating vector. In order to control for crosssectional dependence, the cross-sectional means of all the data series are removed prior to the cointegration test procedures as suggested by Levin, Lin, and Chu (2002).

\section{5 | Panel estimation techniques}

In order to establish robust empirical inferences, the Fully Modified Ordinary Least Squares (FMOLS), the Dynamic Ordinary Least Squares (DOLS) and the Fixed Effects Ordinary Least Squares OLS (FE-OLS) are all employed to ascertain the long-run cointegration coefficients. The Fixed Effects-OLS technique is augmented with Driscoll and Kraay standard errors, which corrects for general forms of cross-sectional dependence and autocorrelation up to a certain lag. Going by the postulations of Pedroni (2004), the foremost reasons of concern in estimating dynamic cointegrated panel have to do with heterogeneity issues. This explicitly entails heterogeneity in means between cross-sections and heterogeneity in cross-sectional adjustment to the cointegrating equilibrium. In order to adequately deal with these issues, Pedroni's FMOLS model is augmented with individual-specific intercepts and controls for heterogeneous serial correlation properties of the error processes across individual members of the panel. The DOLS estimator is incorporated into the panel framework by Kao and Chiang (2001). With regard to results of Monte Carlo simulations, the DOLS estimator is found to be unbiased relative to both the OLS and FMOLS estimators in finite samples. In the DOLS estimation framework, endogeneity is also controlled for by a parametric procedure of lead and lagged difference augmentations in order to suppress the endogenous feedback. 


\section{6 | Panel Granger causality testing procedure}

The empirical analysis concludes with Granger causality testing among the variables. Considering that the variables employed in the empirical analysis all follow I(1) processes, the standard Wald tests for zero restrictions on the Vector Autoregressive (VAR) would not be appropriate for this model. Toda and Yamamoto (1995) develop a modified Wald (MWALD) test in a lag augmented VAR (LA-VAR). This approach can be employed regardless of whether the variables are I(0) or I(1) processes. The $t$-statistics of the LA-VAR follows an asymptotic chi-square distribution when a VAR $(p+d m a x)$ is estimated. The maximum order of integration is denoted by dmax, while $p$ is the lag order. The LA-VAR approach can asymptotically avoid size distortion problems and is augmented with redundant lag(s) which corresponds to the maximum order of integration, dmax. In order to validate the existence or nonexistence of long-run causality, we employ the panel Granger causality framework proposed by Emirmahmutoglu and Kose (2011). Employing the metaanalysis procedures of Fisher (1932), Emirmahmutoglu and Kose (2011) extend the LA-VAR approach of Toda and Yamamoto (1995) to the panel framework in order to test the null hypothesis of no Granger causality. This statistical technique is adequate for non-stationary heterogeneous mixed panels.

To accommodate for cross-sectional dependence in panels, we use the bootstrap procedure outlined in Emirmahmutoglu and Kose (2011) in order to obtain the empirical distribution of the test statistic. The Emirmahmutoglu and Kose (2011) framework can be depicted in the following heterogeneous panel VAR $\left(k_{i}+d\right.$ max $\left._{i}\right)$ model:

$$
\begin{aligned}
& x_{i t}=\psi_{i}^{x}+\sum_{j=1}^{k_{i}+d \max _{i}} \beta_{11, j} x_{i t-j}+\sum_{j=1}^{k_{i}+d \max x_{i}} \beta_{12, i j} y_{i t-j}+u_{i t}^{x} \\
& y_{i t}=\psi_{i}^{y}+\sum_{j=1}^{k_{i}+d \max x_{i}} \beta_{21, i j} x_{i t-j}+\sum_{j=1}^{k_{i}+d m a x_{i}} \beta_{22, i j} y_{i t-j}+u_{i t}^{y}
\end{aligned}
$$

From (3) and (4) $i$ denote country-specific units while $t$ denotes time periods. $\psi_{i}$ denotes country specific fixed effects. $\beta_{11}, \beta_{12}, \beta_{21}$ and $\beta_{22}$ are parameters that are allowed to vary across countries while $u_{i t}$ is the stochastic error term which is independently and identically distributed (i.i.d) for all time periods across countries. The lag order $k_{i}$ and the maximal order of integration $d_{m a x}$ are both allowed to differ across country units.

\section{4 | EMPIRICAL RESULTS}

A cursory look at Table 2 shows that Fll seems to be the most volatile of all the variables when its mean and standard deviation are directly compared. Comparing the between and within standard deviation values shows the need to control for cross-country heterogeneity as they tend to be markedly different in most of the variables. Except for FDI, the between standard deviation values tend to be significantly larger than the within values indicating higher data disparities across countries.

The Pesaran (2004) CD test for cross-sectional dependence in Table 3 Panel A shows that all the variables exhibit cross-sectional dependence; thus, empirical techniques that control for crosssectional dependence should also be incorporated in the analysis. From Table 3 Panel B, the results of the Pesaran (2007) crosssectional augmented Dickey-Fuller unit root test which incorporates heterogeneous auto-regressive parameters across sections show that all the variables are I(1) processes and thus it becomes appropriate to proceed with the cointegration test procedures.

Moving on to the panel cointegration test results in Table 4, it can be seen that both test procedures employed give a robust support for cointegration. From Table 5, inferences obtained from the longrun coefficients imply that FINDI and FII both have contrasting relationships with sustainable development even though the magnitude of the effect of financial development is quite greater. While financial

\begin{tabular}{|c|c|c|c|c|c|}
\hline Variables & & Mean & Std. dev. & Min & Max \\
\hline \multirow[t]{3}{*}{ ANS } & Overall & -1.8674 & 19.93819 & -97.7903 & 36.0927 \\
\hline & Between & & 18.25926 & -67.4496 & 26.6228 \\
\hline & Within & & 7.674724 & -32.2081 & 56.3833 \\
\hline \multirow[t]{3}{*}{ FDI } & Overall & 5.2015 & 9.71954 & -6.0572 & 103.337 \\
\hline & Between & & 6.08033 & -0.2685 & 29.6320 \\
\hline & Within & & 7.65158 & -20.687 & 78.9068 \\
\hline FII & Within & & .942441 & -5.989876 & 6.239736 \\
\hline \multirow[t]{3}{*}{ LFINDI } & Overall & -1.9914 & 0.577153 & -4.710531 & -0.46729 \\
\hline & Between & & 0.557693 & -3.08512 & -0.57175 \\
\hline & Within & & 0.173976 & -3.71670 & -1.38438 \\
\hline RRENT & Overall & 12.4386 & 11.62121 & .0011335 & 59.61957 \\
\hline
\end{tabular}

TABLE 2 Variables summary statistics 
TABLE 3 Cross-sectional dependence and panel unit root tests

\begin{tabular}{|c|c|c|c|c|c|}
\hline & ANS & FII & FINDI & FDI & RRENT \\
\hline Panel A: Pesaran (2004) CD test & $4.43^{* * *}$ & $33.42^{* * *}$ & $28.86^{* * *}$ & $5.52^{* * *}$ & $8.66^{* * *}$ \\
\hline $\begin{array}{l}\text { Panel B: Pesaran (2007) } \\
\text { Panel unit root test [levels] }\end{array}$ & 0.337 & 6.437 & -0.427 & 0.320 & 1.040 \\
\hline $\begin{array}{l}\text { Pesaran (2007) } \\
\text { Panel unit root test. [first difference] }\end{array}$ & $-7.517^{* * *}$ & $-6.451^{* * *}$ & $-7.578^{* * *}$ & $-10.556^{* * *}$ & $-7.232^{* * *}$ \\
\hline
\end{tabular}

Note: ${ }^{* * *}$ denotes statistical significance at the $1 \%$ level. Unit root tests are augmented with 1 lag, inference is obtained via the Zt-bar statistics. Source: Authors' computations.

TABLE 4 Panel cointegration test results

\begin{tabular}{lll}
$\begin{array}{l}\text { Cointegration } \\
\text { tests }\end{array}$ & & \\
\hline Kao (1999) & Modified dickey-fuller t & $-2.7182^{* * *}$ \\
& Dickey-fuller t & $-6.6186^{* * *}$ \\
& Augmented dickey-fuller t & -0.9665 \\
& Unadjusted modified dickey- & $-11.547^{* * *}$ \\
& $\quad$ fuller t & \\
\hline Pedroni (1999, & Modjusted dickey-fuller t & $-10.697^{* * *}$ \\
\hline 2004) & Modified Phillips-Perron t & $5.4194^{* * *}$ \\
& Phillips-Perron t & $-8.378^{* * *}$ \\
& Augmented dickey-fuller t & $-9.645^{* * *}$ \\
\hline
\end{tabular}

Note: ${ }^{* * *}$ denotes statistical significance at the $1 \%$ level. The model is augmented with 1 lag prior to testing and includes an intercept. Crosssectional means are removed to control for cross-sectional dependence. Source: Authors' computations.

development (FINDI) has a negative relationship, financial inclusion on the other hand has a positive relationship with sustainable development. The negative relationship between financial development and sustainable development is consistent with Adeniyi et al. (2015) where financial development is shown to have a mitigation effect on economic growth in Nigeria, it is however inconsistent with studies by Koirala and Pradhan (2020) wherein a negative relationship between financial development and resource rent is uncovered for 12 Asian countries and Madsen et al. (2018:2) wherein financial development is shown to foster sustainable development by bridging the inequality gaps in 21 OECD economies. The inconsistencies of these studies with the present study may not be unconnected with the differences in the economic structure of the different study locations. SSA economies are largely resource-based economies and are a lot less industrialized compared to their Asian and OECD counterparts. The results are robust to the three-panel specifications employed in the empirical analysis. The positive effect of financial inclusion is consistent with other studies in the literature (Lenka \& Bairwa, 2016; Sarma \& Pais, 2011). This goes to show that these two variables capture different aspects of the financial sector in SSA countries. FDI and the resource rents control variable, both also have contrasting relationships with sustainable development. While resource rent as expected has a negative relationship, FDI on the other hand has a positive
TABLE 5 Panel estimation results

\begin{tabular}{llll} 
Variables & FMOLS & DOLS & FE-OLS \\
\hline FII & $0.280495^{* * *}$ & $0.212465^{* * *}$ & $0.2853166^{* * *}$ \\
FINDI & $-3.407577^{* * *}$ & $-6.703017^{* * *}$ & $-3.395679^{* *}$ \\
\hline FDI & $0.063164^{* *}$ & $0.303264^{* * *}$ & $0.1626797^{* *}$ \\
\hline RRENT & $-0.568803^{* * *}$ & $-0.63171^{* * *}$ & $-0.491781^{* * *}$ \\
\hline
\end{tabular}

Note: ${ }^{* * *}$ and ${ }^{* *}$ denote statistical significance at the $1 \%$ and $5 \%$ levels respectively. For the DOLS model, lag augmentation follows the Schwarz Bayesian Information Criterion. The FE-OLS procedure controls for crosssectional dependence via Driscoll and Kraay Standard errors.

Source: Authors' computations.

relationship. The negative relationship between resource rent and sustainable development is also consistent with the resource curse hypothesis (Corden \& Neary, 1982; Ike, Usman, \& Sarkodie 2020; Nwaka et al., 2020, Sachs \& Warner, 2001), while the positive effect of FDI may imply a positive externality effect of FDI on the non-pollution-intensive service sector of SSA economies. To get a clearer picture of the interlinkages among the variables, we proceed to the panel Granger causality results.

The Panel Granger causality test results in Table 6 show that of all the variables employed in the model only FDI has long-run predictive content for sustainable development due to unidirectional causality flowing from FDI to sustainable development. Bidirectional causality exists between FDI and FII and also between FDI and FINDI implying that financial development and financial inclusion may affect sustainable development through their effect on FDI. This is consistent with Azman-Saini et al. (2010) and Choong (2012) where it has been postulated that strong financial sectors are required for the positive effect of FDI to be felt in an economy. There also exists a unidirectional causal flow from FDI to resource rents which implies that FDI is largely attracted to resource extraction in SSA economies and validates the resource seeking FDI hypothesis in SSA economies.

\section{1 | Discussions}

Our study investigates the implications of financial development and financial inclusion on the achievement of sustainable development in SSA, and in addition controlling for resource rent and FDI. This study 
TA B LE 6 Panel Granger causality analysis. (Emirmahmutoglu and Kose (2011))

\begin{tabular}{|c|c|c|c|c|c|}
\hline Variables & \multicolumn{5}{|c|}{$\leftarrow$ Causal direction (causing variables) } \\
\hline ANS & - & $\begin{array}{l}82.330^{* *} \\
{[0.037]} \\
(0.084)\end{array}$ & $\begin{array}{l}113.892 \\
{[0.603]} \\
(0.000)\end{array}$ & $\begin{array}{l}72.360 \\
{[0.939]} \\
(0.276)\end{array}$ & $\begin{array}{l}93.406 \\
{[0.760]} \\
(0.015)\end{array}$ \\
\hline FDI & $\begin{array}{l}53.927 \\
{[0.856]} \\
(0.210)\end{array}$ & - & $\begin{array}{l}77.009^{* *} \\
{[0.046]} \\
(0.167)\end{array}$ & $\begin{array}{l}104.113^{* *} \\
{[0.030]} \\
(0.002)\end{array}$ & $\begin{array}{l}104.029 \\
{[0.122]} \\
(0.002)\end{array}$ \\
\hline FII & $\begin{array}{l}41.788 \\
{[0.992]} \\
(0.991)\end{array}$ & $\begin{array}{l}197.172^{* * *} \\
{[0.006]} \\
(0.000)\end{array}$ & - & $\begin{array}{l}179.700 \\
{[0.222]} \\
(0.000)\end{array}$ & $\begin{array}{l}55.606 \\
{[0.876]} \\
(0.815)\end{array}$ \\
\hline FINDI & $\begin{array}{l}97.347 \\
{[0.540]} \\
(0.007)\end{array}$ & $\begin{array}{l}91.594^{* *} \\
{[0.040]} \\
(0.020)\end{array}$ & $\begin{array}{l}47.069 \\
{[0.948]} \\
(0.962)\end{array}$ & - & $\begin{array}{l}78.879 \\
{[0.985]} \\
(0.133)\end{array}$ \\
\hline
\end{tabular}

Note: ${ }^{* * *}$ and ${ }^{* *}$ denote statistical significance at the $1 \%$ and $5 \%$ level respectively. The procedure employs 2000 bootstrap replications to control for cross-sectional dependence.

demonstrates the significant impact of all the macroeconomic variables employed on sustainability. However, while financial inclusion and FDI found to be positive, financial development and resource rent were found to be negative. This is an indication that financial inclusion proves to be a strong determinant for achieving sustainable development in SSA countries. The results obtained from both panel estimation and panel Granger causality procedures show that a wider reach of financial services in SSA economies can actually encourage sustainable production practices as can be seen from the positive relationship between FII and sustainable development, small- and medium-scale enterprises which are largely oriented towards service delivery are some of the businesses that may likely benefit from higher aggregate financial inclusion. Also, the negative relationship between financial development and sustainable development shows that unsustainable production practices may have more access to credit facilities because these practices tend to yield the highest returns in SSA economies. Production practices that involve forest depletion and resource extraction as well as pollution intensive industrial activities may tend to have greater access to credit facilities. Moreover, the negative effect of financial development on sustainable development might be unconnected with the countries per capital income which is below global average in most of the countries in the panel. This is right because if the income level increases, people demand for more financial services therefore increases financial intermediation and in turn spurs sustainable development. Controlling for the effect of resource rents in the panel regressions ensures that only the positive effect of FDI is isolated in the panel regressions thus the positive relationship between FDI and sustainable development when resource rents are controlled for.

Granger causality tests show that both financial variables affect sustainable development through the foreign investment channel. The inflow of foreign investment to certain hitherto isolated areas may attract financial services to these areas which may markedly improve financial inclusion. Greater improvement in financial inclusion by way of access to financial services can also further attract FDI bringing about bidirectional causality between financial inclusion and FDI. The same scenario also holds for financial development as the inflow of foreign capital can greatly stimulate the provision of credit facilities to these investments by financial institutions in order to partake in their investment returns. These financial institutions can also create financial incentives to attract foreign capital which thus brings about a bidirectional causal relationship between financial development and sustainable development. However, FDI can affect the economy in both a sustainable and unsustainable way. FDI channeled towards resource extraction and pollution intensive production can mitigate sustainable development as can be seen from the unidirectional causal flow from FDI to resource rents. Also, FDI can crowd in domestic investment and generate a positive externality effect on sustainable production activities. This can also be seen from the unidirectional causal flow from FDI to sustainable development.

\section{5 | CONCLUSION AND POLICY IMPLICATIONS}

The present study investigates the causal relationship between financial inclusion, financial development, FDI and sustainable development while controlling for the effect of resource rents. Panel unit root tests show that all the variables in the model are integrated of the first order or I(1). Panel cointegration tests validate the existence of a robust long-run relationship amongst the variables. Panel estimation procedures uncover a positive and significant relationship between financial inclusion and sustainable development, a negative and significant relationship between financial development and sustainable 
development and a positive and significant relationship between FDI and sustainable development. Panel Granger causality analysis uncovers the intermediation effect of FDI. This is to say that the effect of financial inclusion and financial development passes through the FDI channel to sustainable development. A bidirectional causal relationship between FDI and financial inclusion, between FDI and financial development as well as a unidirectional causal flow from FDI to sustainable development gives credence to this postulation. The present study shows that FDI has both a sustainable and unsustainable component depending on which sector of the economy it flows into. A unidirectional causal flow from FDI to sustainable development uncovers the sustainable aspect of FDI, while a unidirectional causal flow from FDI to resource rents uncovers the unsustainable aspect of FDI. In addition, financial inclusion reveals to have much impact on the achievement of sustainable development in SSA, owing to its coefficient $(-3.408)$ which indicate that a percentage change in financial inclusion will reduce the rate of achieving sustainable development in the region. Thus, it is imperative for the policymakers in SSA countries to optimize the level of financial development which requires a vigorous improvement so as to ensure higher potential benefits for the sustainability of SSA region through the financial sector. Moreover, policymakers should include incentivizing the inflow of FDI to the cleaner sectors of the economy in order to ensure sustainable development. This may include tax-cuts to foreign investments oriented towards these sectors and various other incentives. Government and other relevant stakeholders should also incentivize financial institutions in order to propel them to make more available credit facilities to the more sustainable and less pollution intensive small- and mediumscale enterprises in order to stimulate sustainable development in the long-run. This would require a certain level of government integrity in order to forestall the temptation to accrue profit from profitable pollution inducing activities (Alhassan et al., 2020). Policymakers should in addition design strategies to improve financial inclusion in the region, in terms of coverage, accessibility and regulations in order to make it possible for financial inclusion to stimulate sustainable development as this appears to be a significant determinant of sustainable development. However, it would be more insightful to exploit the possibility of another indicator for sustainable development and also investigate the asymmetric effects of the macroeconomic variables employed in this study on sustainable development in SSA. We leave these for future research.

\section{ORCID}

Jamiu Adetola Odugbesan (D) https://orcid.org/0000-0003-3301-396X George lke (D) https://orcid.org/0000-0001-7100-6598 Gbolahan Olowu (D) https://orcid.org/0000-0002-0183-7238 Bosede Ngozi Adeleye (D) https://orcid.org/0000-0002-1274-714X

\section{REFERENCES}

Abdi, H., \& Williams, L. J. (2010). Principal component analysis. Wiley Interdisciplinary Reviews: Computational Statistics, 2(4), 433-459.

Acemoglu, D., \& Wolitzky, A. (2015). Sustaining cooperation: Community enforcement vs. specialized enforcement (no. w21457). Cambridge, MA:
National Bureau of Economic Research. https://doi.org/10.3386/ w21457

Acheampong, A. O. (2019). Modelling for insight: Does financial development improve environmental quality? Energy Economics, 83, 156-179.

Adegbite, O. O., \& Machethe, C. L. (2020). Bridging the financial inclusion gender gap in smallholder agriculture in Nigeria: An untapped potential for sustainable development. World Development, 127, 104755.

Adeniyi, O., Oyinlola, A., Omisakin, O., \& Egwaikhide, F. O. (2015). Financial development and economic growth in Nigeria: Evidence from threshold modelling. Economic Analysis and Policy, 47, 11-21.

Adeola, O., \& Evans, O. (2017). Financial inclusion, financial development, and economic diversification in Nigeria. The Journal of Developing Areas, 51(3), 1-15.

Alhassan, A., Usman, O., Ike, G. N., \& Sarkodie, S. A. (2020). Impact assessment of trade on environmental performance: accounting for the role of government integrity and economic development in 79 countries. Heliyon, 6(9), e05046.

Anarfo, E. B., \& Abor, J. Y. (2020). Financial regulation and financial inclusion in sub-Saharan Africa: Does financial stability play a moderating role? Research in International Business and Finance, 51, 101070.

Anwar, S., Shabir, G., \& Hussain, Z. (2011). Relationship between financial sector development and sustainable economic development: Time series analysis from Pakistan. International Journal of Economics and Finance, 3(1), 262-271. https://doi.org/10.5539/ijef.v3n1p262.

Asif, M., Khan, K. B., Anser, M. K., Nassani, A. A., Abro, M. M. Q., \& Zaman, K. (2020). Dynamic interaction between financial development and natural resources: Evaluating the 'resource curse' hypothesis. Resources Policy, 65, 101566.

Azman-Saini, W. N. W., Law, S. H., \& Ahmad, A. H. (2010). FDI and economic growth: New evidence on the role of financial markets. Economics Letters, 107(2), 211-213.

Babajide, A. A., Adegboye, F. B., \& Omankhanlen, A. E. (2015). Financial inclusion and economic growth in Nigeria. International Journal of Economics and Financial Issues, 5(3), 629-637.

Beck, T., \& Poelhekke, S. (2017). Follow the money: Does the financial sector intermediate natural resource windfalls. CEPR Discussion Paper 11872.

Beck, T., Demirgüç-Kunt, A., \& Levine, R. (2000). A new database on the structure and development of the financial sector. World Bank Economic Review, 14(3), 597-605.

Beck, T., Demirgüç-Kunt, A., \& Levine, R. (2010). Financial institutions and markets across countries and over time. World Bank Economic Review, 24(1), 77-92.

Ceres (2016) The ceres roadmap for sustainability: Financial services. Available from http://www.ceres.org/roadmap-assessment/sectoranalyses/financial-services.

Choong, C. K. (2012). Does domestic financial development enhance the linkages between foreign direct investment and economic growth? Empirical Economics, 42(3), 819-834.

Čihák, M., Mare, D. S., \& Melecky, M. (2016). The nexus of financial inclusion and financial stability: A study of trade-offs and synergies, Washington D.C.: The World Bank.

Corden, W. M., \& Neary, J. P. (1982). Booming sector and deindustrialisation in a small open economy. The Economic Journal, 92 (368), 825-848.

Demirguc-Kunt, A., Klapper, L., \& Singer, D. (2017). Financial inclusion and inclusive growth: A review of recent empirical evidence, Washington D.C.: The World Bank.

Department of Economic and Social Affairs. (2013). Sustainable development challenges. New York, NY: United Nations.

Emirmahmutoglu, F., \& Kose, N. (2011). Testing for granger causality in heterogeneous mixed panels. Economic Modelling, 28(3), 870-876.

Ernst \& Young Global Limited (2015) EMEIA Financial Services Sustainability Report 2015. Available from http://www.ey.com/Publication/ 
vwLUAssets/ey-fostering-sustainability-in-financial-services/\$FILE/ ey-emeia-financial-services-sustainability-report-2014.pdf

Evans, O. (2016). Determinants of financial inclusion in Africa: A dynamic panel data approach. University of Mauritius Research Journal, 22, 310-336.

Gharleghi, B., \& Jahanshahi, A. A. (2020). The way to sustainable development through income equality: The impact of trade liberalisation and financial development. Sustainable Development., 28, 990-1001. https://doi.org/10.1002/sd.2051

Gnègnè, Y. (2009). Adjusted net saving and welfare change. Ecological Economics, 68(4), 1127-1139.

Hatemi-J, A., \& Shamsuddin, M. (2016). The causal interaction between financial development and human development in Bangladesh. Applied Economics Letters, 23(14), 995-998.

Hess, P. (2010). Determinants of the adjusted net saving rate in developing economies. International Review of Applied Economics, 24(5), 591-608.

Ibrahim, M., Alagidede, P., (2016). Effect of financial development on economic growth in sub-Saharan Africa: Does sectoral growth matter? Paper presented at the 1st African review of economics and Finance conference; August 11-12, KNUST, Kumasi.

Ibrahim, M., \& Alagidede, P. (2018). Nonlinearities in financial development-economic growth nexus: Evidence from sub-Saharan Africa. Research in International Business and Finance, 46, 95-104.

Ike, G. N., Usman, O., \& Sarkodie, S. A. (2020). Testing the role of oil production in the environmental Kuznets curve of oil producing countries: New insights from method of moments quantile regression. Science of the Total Environment, 711, 135208.

International Monetary Fund. (2019). Regional economic outlook. SubSaharan Africa: Navigating uncertainty. Washington, DC: International Monetary Fund.

International Monetary Fund. (2020). Regional economic outlook. SubSaharan Africa: COVID-19: An unprecedented threat to development. Washington, DC: International Monetary Fund.

Jeanneney, S. G., \& Kpodar, K. (2011). Financial development and poverty reduction: Can there be a benefit without a cost? The Journal of Development Studies, 47(1), 143-163.

Kaiser, H. F. (1961). A note on guttman's lower bound for the number of common factors 1. British Journal of Statistical Psychology, 14(1), 1-2.

Kao, C. (1999). Spurious regression and residual-based tests for cointegration in panel data. Journal of Econometrics, 90(1), 1-44.

Kao, C., \& Chiang, M.H. (2001). On the estimation and inference of a cointegrated regression in panel data. Nonstationary panels, panel cointegration, and dynamic panels, United Kingdom: Emerald Group Publishing Limited.

Kim, D. W., Yu, J. S., \& Hassan, M. K. (2018). Financial inclusion and economic growth in OIC countries. Research in International Business and Finance, 43, 1-14.

Koirala, B. S., \& Pradhan, G. (2020). Determinants of sustainable development: Evidence from 12 Asian countries. Sustainable Development, 28 (1), 39-45.

Lange, G. M., Wodon, Q., \& Carey, K. (Eds.). (2018). The changing wealth of nations 2018: Building a sustainable future. Washington, DC: The World Bank.

Le, T. H., Chuc, A. T., \& Taghizadeh-Hesary, F. (2019). Financial inclusion and its impact on financial efficiency and sustainability: Empirical evidence from Asia. Borsa Istanbul Review, 19(4), 310-322.

Le, T. H., Le, H. C., \& Taghizadeh-Hesary, F. (2020). Does financial inclusion impact $\mathrm{CO} 2$ emissions? Evidence from Asia. Finance Research Letters, 34, 101451.

Lenka, S. K., \& Bairwa, A. K. (2016). Does financial inclusion affect monetary policy in SAARC countries? Cogent Economics \& Finance, 4(1), 1127011.

Levin, A., Lin, C.-F., \& Chu, C.-S. J. (2002). Unit root tests in panel data: Asymptotic and finite-sample properties. Journal of Econometrics, 108, 1-24.
Li, S., Zhang, J., \& Ma, Y. (2015). Financial development, environmental quality and economic growth. Sustainability, 7(7), 9395-9416.

Madsen, J. B., Islam, M. R., \& Doucouliagos, H. (2018). Inequality, financial development and economic growth in the OECD, 1870-2011. European Economic Review, 101, 605-624.

Matthews, R. A., \& Anne, H. (2010). Sustainable development and climate change. International Affairs, 85(6), 1117-1128. https://doi.org/10. 1111/j.1468-2346.2009.00852.x

Nourry, M. (2008). Measuring sustainable development: Some empirical evidence for France from eight alternative indicators. Ecological Economics, 67(3), 441-456.

Nwaka, I. D., Nwogu, M. U., Uma, K. E., \& Ike, G. N. (2020). Agricultural production and $\mathrm{CO} 2$ emissions from two sources in the ECOWAS region: New insights from quantile regression and decomposition analysis. Science of the Total Environment, 748, 141329.

Odugbesan, J. A., \& Rjoub, H. (2019). Relationship among HIV/AIDS prevalence, human capital, good governance, and sustainable development: Empirical evidence from sub-Saharan Africa. Sustainability, 11(5), 1348.

Olowu, G., Bein, M., \& Olasehinde-Williams, G. (2018). Examining the relationship between financial development, sustainable economic opportunity and ecological footprint in sadc countries. Applied Ecology and Environmental Research, 16(5), 7171-7190.

Olowu, G., Olaseinde-Williams, G. O., \& Bein, M. (2019). Does financial and agriculture sector development reduce unemployment rates? Evidence from southern African countries. Agricultural Economics, 65(5), 223-231.

Pardi, F., Salleh, A.M, \& Nawi, A.S (2015). A Conceptual Framework on Adjusted Net Saving Rate as the Indicator for Measuring sustainable development in Malaysia. Journal of Technology Management and Business, 2(2), 1-10.

Park, S. D. (2018). The nexus of FDI, R\&D, and human capital on chinese sustainable development: Evidence from a two-step approach. Sustainability, 10(6), 2063.

Park, D., \& Shin, K. (2017). Economic growth, financial development, and income inequality. Emerging Markets Finance and Trade, 53(12), 27942825.

Pedroni, P. (1999). Critical values for cointegration tests in heterogeneous panels with multiple regressors. Oxford Bulletin of Economics and statistics, 61(S1), 653-670.

Pedroni, P. (2004). Panel cointegration: asymptotic and finite sample properties of pooled time series tests with an application to the PPP hypothesis. Econometric theory, 597-625.

Pesaran, HM. (2004). General diagnostic tests for cross section dependence in panels' IZA Discussion Paper No. 1240.

Pesaran, M. H. (2007). A simple panel unit root test in the presence of cross-section dependence. Journal of Applied Econometrics, 22(2), 265-312.

Phillips, P. C., \& Sul, D. (2003). Dynamic panel estimation and homogeneity testing under cross section dependence. The Econometrics Journal, 6(1), 217-259.

Pradhan, R. P., Arvin, M. B., \& Bahmani, S. (2018). Are innovation and financial development causative factors in economic growth? Evidence from a panel granger causality test. Technological Forecasting and Social Change, 132, 130-142.

Sachs, J. D., \& Warner, A. M. (2001). The curse of natural resources. European Economic Review, 45(4-6), 827-838.

Sarma, M., \& Pais, J. (2011). Financial inclusion and development. Journal of International Development, 23(5), 613-628.

Soumaré, I. (2015). Does FDI improve economic development in north African countries? Applied Economics, 47(51), 5510-5533.

Svirydzenka, K. (2016). Introducing a new broad-based index of financial development, Washington D.C: International Monetary Fund.

Thiry, G., \& Cassiers, I. (2010). Alternative indicators to GDP: Values behind numbers. Adjusted net savings in question. Discussion papers IRES, (2010-18). 
Toda, H. Y., \& Yamamoto, T. (1995). Statistical inference in vector autoregressions with possibly integrated processes. Journal of Econometrics, 66, 225-250.

Uddin, G. S., Shahbaz, M., Arouri, M., \& Teulon, F. (2014). Financial development and poverty reduction nexus: A cointegration and causality analysis in Bangladesh. Economic Modelling, 36, 405-412.

Weber, O., Diaz, M., \& Schwegler, R. (2014). Corporate social responsibility of the financial sector - strengths, weakness and impact on sustainable development. Sustainable Development, 22(5), 321-335.

Weber, O., \& Finance, S. (2018). The financial sector and the SDGs: Interconnections and future directions, Ontario: Centre for International Governance Innovation, University of Waterloo. Available from. http:// cifango.org/uploads/XVII_slides/OlafWeber-CIFA2019-UNpresentation.pdf

Yin, X., Xu, X., Chen, Q., \& Peng, J. (2019). The sustainable development of financial inclusion: How can monetary policy and economic fundamental interact with it effectively? Sustainability, 11(9), 2524.

Zarsky, L., \& Gallagher, K. P. (2012). No miracle drug: Foreign direct investment and sustainable development. In International investment for sustainable development (pp. 26-58). Oxfordshire: Routledge.

\section{AUTHOR BIOGRAPHIES}

Odugbesan Jamiu Adetola holds a PhD in Business Administration from the Cyprus international university. His research interest spans the domains of sustainable development, development economics and health economics and management.
George lke obtained his PhD from the Eastern Meditteranean University. His research interests include development economics, tourism economics, environmental and energy economics and monetary policy.

Gbolahan Olowu works in the department of business administration Cyprus international university. His research interest focuses on development studies, financial development, African development and agricultural development.

Bosede Ngozi Adeleye works in the department of economics Covenant university. Her research interests are tailored towards income inequality, ICT4development, financial economics, environmental economics and agricultural economics.

How to cite this article: Odugbesan JA, Ike G, Olowu G, Adeleye BN. Investigating the causality between financial inclusion, financial development and sustainable development in Sub-Saharan Africa economies: The mediating role of foreign direct investment. J Public Affairs. 2020;e2569. https://doi.org/10.1002/pa.2569 